\title{
NURTURING STUDENTS' WRITING NARRATIVE INTEREST THROUGH MIND MAPPING AND COOPERATIVE INTEGRATED READING AND WRITING
}

\author{
Ratih Inayah \\ English Department, Faculty of Language Education, Institut Keguruan dan Ilmu Pendidikan (IKIP) \\ Siliwangi, Indonesia \\ E-mail: ratih.inayah@gmail.com \\ Ningtyas Orilina Argawati \\ English Department, Faculty of Language Education, Institut Keguruan dan Ilmu Pendidikan (IKIP) \\ Siliwangi, Indonesia \\ E-mail: tyas.orilina@yahoo.com
}

\begin{abstract}
APA Citation: Inayah, R., \& Argawati, N. O. (2019). Nurturing Students' Writing Narrative Interest Through Mind Mapping and Cooperative Integrated Reading and Writing. Indonesian EFL Journal, 5(2), 121-130. doi: 10.25134/ieflj.v5i2.1781.
\end{abstract}

Abstract: This study aims to investigate the motivation of senior high school students at $11^{\text {st }}$ grade in reading and writing English texts, especially narrative text. The study also explores the insight toward the use of mind mapping and cooperative integrated reading and writing in nurturing students' interest and motivation in writing narrative text. The study used qualitative case study to learn and pay attention to phenomena that the students' motivation in reading and writing narrative text are needed to be nurtured. There were 36 students of $11^{\text {st }}$ grade in senior high school in Bandung were involved in this study. Questionnaire and interview were given to the students. The results show that the students who show positive view toward reading and writing narrative texts are $74 \%$ students. They interest and willingness in making mind mapping of the narrative, because they know that narratives texts are full of information and moral value. While only $26 \%$ students who seem force to read and write narratives text to compose mind mapping. Eventually, integrating reading and composition in the classroom can nurture their reading interest and increase their willingness to read narrative text. Since, many students can understand the moral value of the narrative text through discussing with their friends at the class and making a mind mapping through cooperative learning about the narrative text is very useful to develop their mind.

Keywords: cooperative learning; mind mapping; narrative text; reading; writing.

\section{INTRODUCTION}

Students at senior high school level are expected to have a great interest into reading and writing of narrative text, especially for those who are at $11^{\text {st }}$ grade. Reading English material is something that cannot be avoided in their daily activity in teaching and learning English. Reading narrative text will be something familiar and students will find it almost every day during their study time of learning English at school. According to Buzan (2012), mind mapping is an alternative thinking of the whole brain towards linear thinking. Mind mapping reaches in all directions and captures various thoughts from all angles. While writing narrative text through mind mapping can be a good way to pour students' idea, this is also growing students' willingness to write in English.

Hamied and Musthafa (2009) explain that reading is cognitive process of understanding a written linguistic message. There are many people who think of reading as a simple and easy activity, however reading narrative text is not always as easy as what many people guess. Somehow, reading is actually complex process that needs a big effort of active participation on the part of the reader (Brown, 2005). Moreover, writing narrative text is considered as hard skill. Nurturing students' interest and habit in reading and writing narrative text is started from our consideration that some students are less enthusiastic when they have to read narrative texts alone without 


\section{Ratih Inayah \& Ningtyas Orilina Argawati}

Nurturing students' writing narrative interest through mind mapping and cooperative integrated reading and writting

participation of other people moreover to rewrite it again.

Accordingly, among those four skills in English, writing is considered as the most difficult skill to be learned independently. This is supported by Alwasilah (2001) who says that writing is considered as the most difficult skill to acquire by everyone and teach by the teachers. This difficulty often caused by the complicated process of writing itself, the experiences of the writers, the background knowledge in which the writers have to focus not only on grammar, vocabulary and mechanism, but also how the ideas expressed, delivered and developed in a proper way. Some students cannot elaborate and generate the ideas form a particular to be written. Thus, some students failed to construct a good writing either in term of fluency or coherent. This fact is in accordance with Nunan (2003) who assume that in term of skill, producing a coherent, fluent, and extended piece of writing is probably the most difficult things to do in language learning.

The genre of reading text that students often find in the year of their study time very often is narrative text. They will spend times to read the literature as part of learning material. We think as a teacher, choosing the best materials for reading in general communication is not simple thing. We must consider their interest instead of forcing the students to read the materials that they are not even interested in it. This research is conducted to nurture students' interest in reading and writing English material. In this research, we try to solve the problems that we often find in the classrooms. The research questions are; 1). How do students interest in Reading and Writing narrative text? and 2). How does cooperative integrated reading and composition by using mind mapping can nurture their reading interest?

To solve the problems in teaching and learning reading and writing, teachers require teaching techniques that is expected to be able to help students to generate their ideas in writing English especially narrative text. Mind mapping are offered to be one of the solutions for those matters. Mind mapping is introduced and developed by Tony Buzan, a professional who always well organized in thinking and elaborating his mind. As explained by Cahyono (2009), it is simply a diagram used to represent words, ideas, or other items linked to and arranged in a free fashion around a central key words or ideas. The usage is expected to help the students to associate and giving ideas, think and do creatively, and make the right connection that might not otherwise make (Buzan, 2010).

Reading and writing is the key of knowledge and we need it to open up our mind. Every single person must have both very essential skills, no matter what field they concern. We usually learn from the texts that we read, and then we try to transfer what we know through writing or composing as supported by Brumitt (2007) especially while we are still learning in school, many things and information that we know are based on what we read. Since writing is the act of pouring what we know in a piece of paper, we must read general and specific information in order to be able to write what is interesting and important for us.

According to Brown (2005), the processes of reading and writing should develop as natural as possible. Sometimes, reading is considered as a force for some students. There are many books and texts that the students have to read during their times learn at school. Somehow, the nature of pouring the materials which they learn is still limited. This is in line with Rodliyah (2016) that students only read what they guess important and sometimes they miss some essential information. In other words, the skill of considering general information and specific information needs extra care.

The development of reading and writing are in the eyes of the using of reading and writing skills during teaching and learning situations. The classroom-learning environment that forces students to read what is important for them is crucial to the successful of reading and writing.

According to Inayah and Rahayu (2015) teachers must be able to understand and apply the importance of teaching reading and writing 
in the same time. Teachers must be able to develop materials that they will teach. A good teacher should be able to make reading and writing alive in the classroom setting. That is a challenge for teacher to bring the reading and writing skill together and meaningful as part of essential skill in students' perspective.

Argawati and Suryani (2017) also point out that the processes of learning to read and write should become intertwined in natural language activities. When reading and writing are taught naturally, then the students will find these as a meaningful activity. On the other hand, Rizqiya, Pamungkas, and Inayah (2017) also emphasize that teachers should provide opportunities for students to understand reading and writing connection between becoming a reader and writer. In our class right now reading and writing are taught at the same time. During the reading activity, students also write what is important to them.

Many students do not know what they read. They do not have clear ideas of what the writer intents to communicate (Nunan, 2003). The problem is they do not read and write effectively and efficiently. Reading and writing in effective and efficient way is very important for students at school because the students must find the main idea of the texts. There are two strategies in reading that the most popular among all. Those are skimming and scanning. When skimming, it means that the students must be able to find the most important information, the most common patterns are a series of questions, such as who, what, where, why, when, and how. The students are expected to be able to read the texts quickly for information about who, what, where, why, when, and how.

As reading skill, skimming is used by students to find general ideas quickly. According to Harmer (2007) there are some reasons to use skimming strategy. First is to anticipate the general content of a chapter they are going to read. Second is to decide if a chapter has the kind of information they are looking for. Third is to get the general idea of a chapter they do not have time to read. The habit also has an effect in skimming strategy because it usually the students move their eyes across the lines rapidly, and they will not stop

\section{https://journal.uniku.ac.id/index.php/IEFLJ/index}

until get what they need, as we know that the first sentence usually prepares the reader for the paragraph. While scanning is a reading technique, that is commonly used by a student to find specific information quickly. Students will do scan to find facts and to answer questions.

According to Buzan (2012), mind mapping is also a great route map for memory, allowing us to arrange facts and thoughts in such a way that the natural workings of the brain are involved from the start. It means that remembering information will be easier and more reliable than using traditional recording techniques. All mind mapping have similarities, everything uses color and everything has a natural structure that radiates from the center. All of them use curved lines, symbols, words, and images that fit a series of rules that are simple, basic, natural, and in accordance with how the brain works. With mind mapping, a long list of information can be transferred to a colorful, highly organized, and easy to remember diagram that works in harmony with the brain's natural way of doing things.

Michalko (2011) states that in the Cracking Creativity book, mind mapping will activate the entire brain, clear the mind of mental clutter, allow us to focus on the subject, show the relationship between parts of information that are mutually exclusive, give a clear picture of the whole and details, allow us to group concepts, help us compare them, and require us to focus on the subject that helps transfer information about it from short-term memory to long-term memory.

There is much research have been done to investigate the implementation of using mind mapping in teaching and learning English in the classroom to empower students' skill and achievement. A research by Fauziah (2017) proves that the reading and writing activity that used mind mapping as a technique seems to be more focus in generating students' idea. Accordingly, using mind mapping technique also had deepened explanation of the topic as well as clear main idea and supporting ideas. In addition, another study conducted by Rahmah (2017) revealed that there is a positive effect in the result of students's 


\section{Ratih Inayah \& Ningtyas Orilina Argawati}

Nurturing students' writing narrative interest through mind mapping and cooperative integrated reading and writting

descriptive writing after using mind mapping technique. Then, a research conducted by Yunus (2016), it investigates the use of mind mapping to enhance writing skill in Malaysia. The result of the study reveals that the technique is effective to enhance writing skill. The major difficulties during the study mostly related to the structure.

This study is aimed to nurture students' interest in writing narrative text by using mind mapping and cooperative integrated reading and writing. According to Kagan and Kagan (2009), cooperative learning is the most extensively researched educational innovation of all time and results are clear. Hundreds of lab and field research studies demonstrate that impact on classroom climate students' selfesteem, empathy, and internal locus of control, role taking abilities, time on task, attendance, acceptance of mainstreamed students, liking for school and learning.

Cooperative learning can be defined as learning based on small group approach in teaching and learning process that holds students accountable for both individual and group achievement (Orlich, 2007). It is strengthened by Jacobs and Hall in Richard and Renandya (2002) state that cooperative learning is a tool consisting some techniques which teachers use to encourage mutual helpfulness in the groups and the active participation of all members. As the cooperation, in the process, cooperative learning is applied in groups.

According to Orlich (2007), each group consists of three to four students. Whereas Musthafa (2008) argues that generally, the most efficient size for each group is four to six. Another opinion is proposed by Jacobs and Hall in Richard and Renandya (2002) that in a group there should be four students. Furthermore, the students work on an assignment or project together in such a way that each group member contributes to the learning process and then learn all the basic concepts being taught.

\section{METHOD}

This study employed a qualitative approach which was considered appropriate to answer our research problems. In this case study, we tried to submit a systemic collection of information about a person and group in social setting. Alwasilah (2011) said that in order to gain meaningful insight related to using mind mapping in reading and writing by using cooperative learning strategy. This research was done in natural setting, and the natural setting was in the classroom. It was considered as a source of direct data, and we are as the part of key instrument. We took the data in the form of words or images, rather than numbers. Then we examined processes as well as outcomes, we tended to analyze the data inductively, and the main focus of our research was how students understand their part as a reader and writer. Then, how to read narrative text became a good habit for students' life in school. From the characteristic above, this research can be classified as qualitative research.

In gaining the data, this research employed various techniques such as classroom observation, interview and students' mind mapping result. In this research, interview was used to gain specific information and opinion or essential data about students' feeling or opinion which was shown through observation (Cresswell, 2010). The participants in the research were students of $11^{\text {st }}$ grade in a senior high school in Bandung. There were 36 students in the class.

At first, we made a group of students which consist of four students as heterogenic as possible, the second we gave narrative texts that was suitable with learning topic. The narrative texts that we gave consist of nine titles, it was based on nine groups in the classroom. The title of narrative texts were Princess Rose and Golden Bird, Rapunzel, Sangkuriang, Lake of Toba, Aladdin and magic lamp, Malin Kundang, Nasredin and the young boy, Beauty and the beast, and The Cursed Prince. The next step was students work together in group and they must read and found the main idea and giving response toward the narrative texts and then in the group they must write a mind mapping about the narrative text that they had read into a piece of paper that we provided. The fourth, 
students should demonstrate and share the result of the group work. Eventually, students and teacher made a conclusion together related to the narrative texts.

To know students' interested in reading and writing narrative text, it was done by spreading questionnaire and interview to them. The questionnaire was given to all 36 students, while the interview was given to high achievers and low achievers in the classroom. In analyzing the data, the researchers tried to integrate and relate the findings to the background of the study, especially to the research questions, theories, and the methodology for classifying the data into manageable units as suggested by Emilia (2008).

\section{RESULTS AND DISCUSSION Students' interest in reading and writing English text}

The genre of text that students always read was narrative text. They would spend time to read literature as a part of learning material. We thought as a teacher, choosing the best materials for reading in general communication was not simple thing, we must

\section{https://journal.uniku.ac.id/index.php/IEFLJ/index}

consider their interest instead of forcing the students to read the materials that they did not even interested in it.

Based on the questionnaire, some students became less enthusiastic in reading a narrative text. Since they did not have a willingness to know what the advantage of reading that text $(30 \%)$. They just did what they were asked to do without knowing the benefit of reading that narrative texts (24\%). However, they have a mindset that to know and understand the materials they have to search by reading through some techniques (70\%). Reading by using scanning technique was more often used than skimming technique $(60 \%)$. Students were only interested to read the materials that they thought will appear in the examination $(80 \%)$. Students often leaved the narrative text in the middle of the way they were reading (50\%). Students had a willingness to read a modern popular narrative rather than the classic one $(70 \%)$. Students had only few times to read narrative text $(50 \%)$. Students obtained moral values from the narrative text that they read $(70 \%)$. Students obtained entertainment from the narratives text $(74 \%)$.

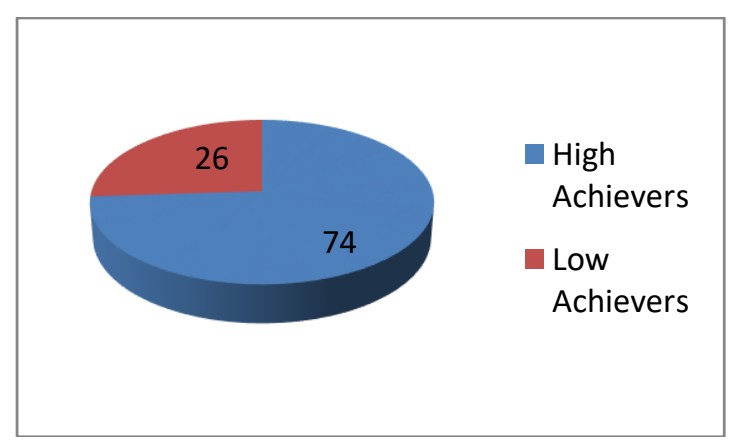

Figure 1. Students motivation reading and writing narrative text

Those percentages from the result of the figure above could representative students' motives and interests in reading and writing narrative text. This was in line with Rodliyah (2016) who stated that narrative text could not be separated from the life of students at school. It means that reading narrative text was a source of knowledge and information to students while writing a mind mapping was an appropriate way to describe students' idea in an interesting way. People wrote a narrative story might be just for pleasure, to attract and get the reader's interest through the story.
Besides, they like to write any kind of story due to they wanted to reflect their own experience and the think that the readers may had similar with the story that written by the researcher.

This is in line with Musthafa (2010) said that some purposes of narrative were to entertain, to express feelings, to relate experience, to inform something happened with someone, to inform something which could teach a lesson to the reader, and to persuade. Brown (2004) emphasized that the generic structures of narrative text, such as: 1). 


\section{Ratih Inayah \& Ningtyas Orilina Argawati}

Nurturing students' writing narrative interest through mind mapping and cooperative integrated reading and writting

Orientation/exposition was the introduction of what was inside the text. What the text was talk in general. Who involved in the text. When and where was happen; 2) Complication/rising action was a crisis arises. The complication was pushed along by a serious of events, during which usually expected some sort of complicating or problem to arise. It explored the conflict among the participant. Complication was the main element of narrative. Without complication, the text was not narrative. The conflict could be shown as natural, social or psychological conflict; 3). Resolution was the crises were resolved. In this part, the implication may be resolved for better or worse, but it was rarely left completely unresolved. Although, it was possible in certain types of narrative which leaved us wondering "How did it end.". The language features of narrative text were: 1). A narrative text usually used past tense; 2 ). The verbs used in narrative were behavioral processes and verbal processes.

From the discussion above, it could be concluded that narrative had several social functions such as to amuse, to entertain, and to deal with actual experiences in different ways. Narrative dealt with the fiction story that can entertain the readers as well. From the interview that was done by researcher, one student who was high achiever (that was known by the rank in the classroom) was interviewed then she answered the questions as natural as possible, "Reading narrative text was one of my favorite activities. I read narrative not only in the classroom of reading class but also at home. I often spent my idle hours to read some narrative text. I also found pleasure in writing a mind mapping to describe narratives text that I have read" (PS).

The answers from PS as a high achiever represented the voices of many students or $74 \%$ who showed positive point of view and it showed how good her response through reading and writing narrative text in a cooperative way by using mind mapping. She showed a high interest and willingness in reading, it proved that she enjoyed reading narrative as a happy activity.
The researchers also did an interview to other student, one student who was low achiever (that was known by the rank in the classroom) was interviewed and he answered the questions as natural as possible. "Reading narrative text was one of the things that I did with force. I did not like reading narrative text because I thought all of narrative text was quite boring, only a few that was interesting. I also hard to make a mind mapping because it was not interesting for me" (FI). The answers from FI as a low achiever showed the truth of many low achievers students who thought that they were forced to read narrative text. He thought that reading a narrative text did not have advantage and he could not find pleasure while he was reading for narratives text.

\section{Integrated reading and writing by using mind mapping and cooperative method}

This was something new for many students, they must think how to re-tell that again in a form of writing. Writing a mind mapping about narrative text was considered as a challenge for some students because they must divided their attention through reading and writing.

The observation was conducted on March, $14^{\text {th }}-$ April, $18^{\text {th }}$. The result of observation was observed to answer the research question about the implementation of mind mapping in integrating reading and writing in cooperative method in learning English. Generally, the teaching and learning process by using mind mapping through cooperative learning was run well. The observation filled by five colleagues in the learning process. The result of observation recorded in the observation sheet. The following described some of the result observation in the use or implementation by using cooperative learning in teaching and learning writing narrative text. Before the learning process started, the students directed to create a group as was determined as the previous to make a group in heterogeneous consisted of 4-5 students.

The result of the observation described that students' activity when they formed a group was well organized. After all students created the groups, the teacher shared the students' 
work sheets of text narrative, and discussed the questions with other students in their group and they must present the result in the end of the learning process. At the discussion, the teacher became the important role to guide the group members who faced the difficulties in solving the problems were given by the teacher. Each of members was given a freedom and flexibility in explained and expressed their opinion or ideas during the discussion. After that the teacher given a quiz in the end of the learning process, and the students with their group answered to compete with another groups.

Based on the observation result, it could be seen that the students who needed help to get the explanation correctly from the teacher when they asked the question to the teacher. The students were cooperative well in group. They could answer the questions and wrote the mind mapping related to narrative text based on their understanding. After the discussion in group was done, the teacher commanded to all groups prepared to present the group result in front of the class and discussed with another groups. After that the students and the teacher concluded the material already learnt by them at that time with reflected the material and evaluated it together. Finally, the teacher gave the rewards for the students and groups' discussion.

The interview was conducted to know about the students' difficulties faced in writing mind mapping related to narrative text. The result of interview was to know the students' difficulties faced by using cooperative learning. The interview consisted of the explanation and opinion from the students who was included as the high, medium, and low student achievers. The researcher took three high students, three middle students, and three low students based on the result score in the data analysis in this research with used initial S1, S2, S3, S4, S5, S6, S7, S8, S9 in order to prevent something unwanted and it could represent the students in the class. For additional information that initial S1, S2, S3 were low achievers, the initial S4, S5, S6 were medium achievers, and the initial S7, S8, S9 were high achievers.
https://journal.uniku.ac.id/index.php/IEFLJ/index

The researchers interviewed the students on Thursday, March $18^{\text {th }}, 2019$ (09.00-10.00). The researcher asked them related to the students' difficulties faced by using problem based learning in writing narrative text. It can be concluded as follows:

\section{Researchers: After learning writing narrative text by using mind mapping, what is your opinion in reading and writing narrative text and what is your difficulty in writing mind mapping?}

S1 : kurang menyenangkan, sulit untuk dipahami. (it was less fun, difficult to understand).

S2 : pembelajaranya sangat menyenangkan, kesulitanya itu dalam mengartikan bahasanya. (the learning activity was very interesting, the difficulty in interpreting the language).

S3 : biasa saja, susah memahami artinya. (just so so, it was hard to understand the meaning).

S4 : pembelajaranya memudahkan saya dalam belajar, kesulitanya kurang begitu paham penulisanya. (the learning activity made me easy to learn, the difficulty was not understand about the writing).

S5 : pembelajaranya mudah dimengerti, kesulitanya ketika guru membacakan dan kita menulisnya. (the learning activity was easy to understand, the difficulty was found when the teacher read and we have to write it).

S6 : kurang menyenangkan, kesulitanya menghapal kata-katanya. (it was less fun, the difficulty in memorizing the words).

S7 : pembelajaranya sangat menarik membuat semangat dalam belajar, kesulitanya dalam mengartikan kata-kata. (the learning activity was very interesting, it made us enthusiasm in learning, the difficulty in interpreting the words).

S8 : pembelajaranya sangat menyenangkan karena bisa menghilangkan rasa bosan, kesulitanya tidak ada. (the learning activity was very fun, because it could eliminate boredom, there was not difficulty).

S9 : pembelajaranya membuat semangat, karena selalu ada hadiah ketika menjawab pertanyaanpertanyaan, kesulitanya dalam mengartikan katakatanya. (the learning activity made enthusiasm, because there were rewards when we answered the questions, the difficulty in interpreting the words).

Based on the description above, it could be seen that some of students had the difficulties with the use structure and grammatical in writing narrative text by using mind mapping. They still confused how to generate their ideas in writing narrative text. Meanwhile, they expressed their opinion that teaching and 


\section{Ratih Inayah \& Ningtyas Orilina Argawati}

Nurturing students' writing narrative interest through mind mapping and cooperative integrated reading and writting

learning writing narrative text by using mind mapping was quite new to be applied in their clasroom. However many students $(74 \%)$ are glad to compose mind mapping, because they were challenged to show that they had a big attention through reading narrative text and they could pour what they catched and understand through writing a mind mapping.

Many students helped each other by discussing what they obtained from the narrative text that they read. The cooperative method was applied by discussing and helped each other to less selfish feeling among students. Cooperative learning offered an alternative way to competitive model of education. It also offered many benefits such as improving both academic learning and social skills.

According to Richard and Renandya (2002), the more benefits were: 1). Greating motivation for learning. As explained before that in cooperative learning group there would be groups of students' work. In doing the activity, they worked in group and support each other; 2) Lessing teacher talk. The students tried to study and did the activities by themselves, led by the leader of the group, and sometimes they asked the teacher for guiding them; 3). Increasing student participation. Each student was pushed to take part in the activities; 4). More varied student talk. The students would have a discussion in their own group. There would be varied talk from each student. They could share freely about the materials and did the activity together with their team-mate; 5). Negotiating of meaning. From the varied talk of the students, there would be many opinions that were shared together and it would ease them to solve the problem in their activity. It would also produce a greater amount of comprehensible input; and 6). Relaxing classroom atmosphere. It would comfort the students in learning process. They would feel that the situation in class was not too strict and formal.

Moreover, there were also some characteristics of cooperative learning stated by Kagan (2009), namely; 1). Using small groups. Each group consisted of three, four, or five students. It depended on the activity; 2).
Focusing on tasks to be accomplished. Together with the team-mate, they should work hard to finish the tasks successfully; 3 ). Requiring group cooperation and interaction. The students worked as team. They should work cooperatively and help each other; and 4). Mandating individual responsibility to learn. Besides as the team-mate, each student was also asked to have the responsibility individually. It supported division of labor, because in cooperative learning, sometimes each student had each own job in team, and they must responsible with their job.

The result of this study was relevant with the previous studies conducted by Rodliyah (2016), Gillies (2016), and Johnson and Johnson (2009) in which the result of their study showed that by integrating reading and writing at the same time, the students got so many advantages. Firstly, they could get more information about the reading materials that they needed to know. Secondly, they could increase their reading skill, because they have to read in appropriate way by using skimming and scanning technique. Thirdly, they could make group a concept through mind mapping. It was very important to know that reading many narrative texts could make the students increased their vocabulary and knowledge skill. Since narrative text were full of knowledge, culture, and moral value. The result of this research also in line with Musthafa (2008) which showed that teaching and learning reading and writing in the same time were effective in nurturing students' interest in learning English.

In teaching and learning writing used cooperative learning, teachers and students found many advantages and new experiences. Those were the type of activities in teaching and learning process that combined cooperative learning procedures and writing process (Rodliyah, 2016). Cooperative writing activities had two aims. The first one was focusing on messages and targeted communication function which was related to fluency and the second one was focusing on form or structure which was related to accuracy. If teacher decided to focus on the first aim, they could use several types of 
Indonesian EFL Journal (IEFLJ)

Volume 5, Issue 2, July 2019

activity such as brainstorming, speed writing, story sequences, etc. However, if they wanted to focus more on the second aim, they could use tasks like group timeline projects.

\section{CONCLUSION}

This study has already answered the research questions by data. The data shows that some students less enthusiastic in reading English text for the reasons that they do not recognize the benefit of reading narrative text for their reading and writing skill. By using mind mapping, students are helped to organize their idea in a proper way. Some students have a big attention toward reading narrative text, since they consider that there are many benefits obtain from reading narrative text. The students show positive view toward reading narrative text. It shows their interest and willingness because they know that narrative texts are full of information and moral value. This moral value drives the students to work in collaborative technique with their friends to discuss a good side and bad side of a character in narrative text.

Integrating reading and composition in the classroom can nurture their interest and increase their willingness to read narrative text, because many students can understand the moral value of the narrative text through discussing with their friends at the class and making a mind mapping about the narrative text in the same time. Cooperative technique in reading and writing are a good technique to keep students' motivation to search and gain new knowledge together also to less selfish behavior. By cooperative integrated reading and writing, they are motivated to share their opinion and ideas with others confidentially without feeling ashamed and doubt.

Furthermore, researchers are expected to explore the characters that alive in narrative text to be explored deeply through discussion and sharing knowledge.

\section{ACKNOWLEDGEMENT}

This study is one of the recipients of Research Grants for Internal Lecturers (Hibah Penelitian Dosen Internal) organized by Lembaga Penelitian dan Pengabdian pada Masyarakat Institut Keguruan dan Ilmu
p-ISSN 2252-7427, e-ISSN 2541-3635

https://journal.uniku.ac.id/index.php/IEFLJ/index

Pendidikan (IKIP) Siliwangi with the year of implementation on 2019. This paper is the result of our hard work and dedication to our beloved campus is Institut Keguruan dan Ilmu Pendidikan (IKIP) Siliwangi.

\section{REFERENCES}

Alwasilah, C. (2011). Pokoknya kualitatif: Dasar-dasar merancang dan melakukan penelitian kualitatif. Bandung: Pustaka Jaya.

Argawati, N. O., \& Suryani, L. (2017). Teaching writing using think-pair-share viewed from students' risk taking. English Review: Journal of English Education, 6(1), 109-116. doi: 10.25134/erjee.v6i1.776.

Brown, H. D. (2005). Teaching by principles: An interactive approach to language pedagogy. New York: Longman Inc.

Buzan, T. (2012). The ultimate book of mind maps. Jakarta: Gramedia Pustaka Utama.

Cahyono, Y. B. (2009). Technique in teaching EFL writing. Malang: State University of Malang Press.

Cresswell, J. W. (2010). Research design: Qualitative \& quantitative approaches. New Delhi: Sage Publications.

Emilia, E. (2008). Menulis tesis dan disertasi. Bandung: Alfabeta.

Fauziah, U. N. E. (2017). The use of mind mapping in generating students' idea. Acuity: Journal of English Language Pedagogy, Literature, and Culture, 2(1), 45-60.

Gillies, R. M. (2016). Cooperative learning: Review of research and practice. Australian Journal of Teacher Education, 41(3).

Hamied, F. A., \& Musthafa, B. (2016). Problematika pengajaran bahasa \& sastra inggris di perguruan tinggi di Indonesia. Jakarta: Depdikbud.

Harmer, J. (2007). How to teach writing. Kuala Lumpur: Pearson Education Limited.

Inayah, R., \& Rahayu, S. (2015). Exploring students' difficulties in comprehending reading for academic material used in their class. Jurnal Ilmiah UPT P2M STKIP Siliwangi, 2(2), 240-245.

Johnson, D., \& Johnson, R. (2009). An educational psychology success story: Social interdependence theory and cooperative learning. Educational Researcher, 38, 365379.

Kagan, S., \& Kagan, M. (2009). Kagan cooperative learning. San Clemente: Kagan Publishing.

Musthafa, B. (2010). Teaching English to young learners in Indonesia: Essential requirements. Educationist, 4(2), 120-125.

Musthafa, B. (2008). Teaching English to young learners: Principles and techniques. Bandung: UPI Press.

Nunan, D. (2003). Practical English language teaching. London: Mc Grow Hill.

Orlich, D. C., et al. (2007). Teaching strategies a guide to effective instruction. Boston: Houghton Mifflin Company. 


\section{Ratih Inayah \& Ningtyas Orilina Argawati}

Nurturing students' writing narrative interest through mind mapping and cooperative integrated reading and writting

Rahmah, U. (2017). The effectiveness of using mind mapping technique on students' writing ability in descriptive text. Mini Thesis. Fakultas Pendidikan Bahasa. UIN SH.

Richard, J. C., \& Willy, A. R. (2002). Methodology in language teaching: An anthology of current practice. Cambridge: Cambridge University Press.

Rizqiya, R. S., Pamungkas, M. Y., \& Inayah, R. (2017). The use of power learning strategy to improve students writing competency. OKARA: Jurnal Bahasa dan Sastra, 11(2), 253-262.

Rodliyah, R. S. (2016). Using a facebook closed group to improve EFL students' writing. Jurnal Ilmu Pendidikan, 82-101.

Yunus, M., \& Hua Chien, C. (2016). The use of mind mapping strategy in Malaysian University English Test (MUET) writing. Creative Education, 7, 619626. doi: 10.4236/ce.2016.74064. 